\title{
Transparent Autocracies: The Extractive Industries Transparency Initiative and Civil Society in Authoritarian States
}

\begin{abstract}
The Extractive Industries Transparency Initiative (EITI) is a public-private partnership that aims to set a global standard in resource management. The EITI has a unique format that requires an active civil society to be part of the resource management process. At the moment, 51 resource-rich countries implement the initiative, including many non-democracies. Building up on the literatures on the resource curse, democratization, norm diffusion and compliance, this paper addresses a critical question: Can the EITI be truly successful in incorporating civil society groups into the decision making process in non-democratic countries? Based on case studies of Azerbaijan and Kazakhstan, it argues that while on paper civil society groups are part of the national multistakeholder process, in practice independent NGOs are finding it more and more difficult to exercise their monitoring and whistleblowing capacities due to political, technical, financial and bureaucratic constraints. In addition, the statistical analysis shows that EITI membership is not correlated with better civil and associational rights in authoritarian countries. These results confirm that despite the initial euphoria regarding civil society participation in the EITI, NGOs remain the weakest link in majority of EITI-implementing states.
\end{abstract}

Keywords: Transparency, Democracy, Compliance, Extractive Industries, Civil Society.

\section{Introduction}

The Extractive Industries Transparency Initiative (EITI) is a coalition of governments, companies, and civil society groups, which aims to improve natural resource management. The EITI membership is voluntary and all resource-rich countries can become members by agreeing to disclose their revenues from the sale of hydrocarbons and minerals. Subsequently, the EITI process obliges all companies operating in the extractive industries to reveal their payments to the government. Currently 51 resourcerich countries implement the EITI standard. In other words, they publish regular reports on their extractive industries and disclose important data on their tax revenues and royalties. As an initiative that exclusively focuses on transparency, the EITI does not 


\section{Kerem Öge - Transparent Autocracies}

have any conditionality clauses on basic democratic and human rights. Consequently, EITI members exhibit a diverse set of political institutions: various authoritarian regimes successfully implement the EITI Standard along with several partial and full democracies.

One might commend the EITI's ability to attract non-democracies, which would not typically agree to liberalize their institutions. Yet, it is not clear whether the EITI can successfully transform natural resource management in authoritarian contexts. As a public-private partnership, the EITI has a unique format that requires an active civil society to be part of the multi-stakeholder group (MSG), which is responsible for overseeing the whole process. While this arrangement functions adequately in democratic countries such as Norway, in many authoritarian EITI members the civil society is weak and under pressure from the government.

This paper addresses the rather unusual phenomenon of transparent autocracies in order to understand how the EITI functions in authoritarian contexts. Building up on the literatures on the resource curse, democratization, norm diffusion and compliance, the paper addresses a critical question: Can the EITI be truly successful in helping civil society groups become key partners in the national MSGs of authoritarian countries?

This paper uses a multimethods research design to address this question. First, drawing on the case studies of Azerbaijan and Kazakhstan, it argues that while on paper non-democratic governments agree to include civil society groups as essential partners in the national MSGs, in practice independent Non-Governmental Organizations (NGOs) often find it difficult to exercise their monitoring and whistleblowing capacities due to political, technical, financial and bureaucratic constraints. Second, based on an 
Kerem Öge - Transparent Autocracies

interrupted time-series (ITS) analysis, the paper shows that political environment for civil society groups in authoritarian EITI-implementing countries do not improve following membership.

The paper begins with a literature review of the interaction between extractive industries, democratic institutions, and civil society. Next, the EITI is introduced as a novel attempt to improve revenue management in resource-rich countries. The succeeding sections present the analytical framework, case studies, and the statistical analysis. The key contribution of this research is empirical. First, it demonstrates the opportunities and challenges faced by civil society actors in Azerbaijan and Kazakhstan based on the author's personal interviews in these two countries at the early stages of the national MSG process in 2010. ${ }^{1}$ Second, the paper uses a statistical model to analyze longer trends on the relationship between the EITI membership and civil and associational liberties in all authoritarian members. As such, this paper bridges the divide between detailed case studies and statistical analyses that is common in the literature on the EITI. Finally, this research also has policy implications as it evaluates the viability of the EITI method of incorporating civil society groups into the national MSG structure in authoritarian countries.

\section{Extractive Industries, Democratic Institutions, and Civil Society}

It has been three decades since scholars began to claim that heavy dependence on natural resources could lead to economic and political problems, thus instigating the vast literature on the so-called resource curse (Auty, 1993; Bruno \& Sachs, 1982; Karl, 1997;

\footnotetext{
${ }^{1}$ The paper draws upon 35 in-depth interviews by the author with government officials, non-governmental organizations, and international financial institutions representatives in Baku, Almaty and Astana conducted in 2010 .
} 


\section{Kerem Öge - Transparent Autocracies}

Sachs \& Warner, 1995). This literature evolved from early arguments that problematized the negative economic effects of resource abundance to more nuanced ones focusing on the institutional causes of slow economic growth and low levels of human well-being in resource-rich countries (Dietsche, 2007; Luong \& Weinthal, 2010; Robinson, Torvik, \& Verdier, 2006; M.L. Ross, 1999; Stevens \& Dietsche, 2008; Van der Ploeg, 2011). According to the latter group of scholars, the negative correlation between natural resource abundance and economic development observed by earlier proponents of the curse is mainly due to lack of "good" institutions (Dietsche, 2007; Sala-i-Martin \& Subramanian, 2003). While weak institutions tend to undermine economic development (Mehlum, Moene, \& Torvik, 2006), well-functioning institutions can offset predatory development policies in resource dependent countries and reduce patronage and corruption. Furthermore, certain institutional qualities such as political accountability and rule of law can positively impact economic growth (Isham, Woolcock, Pritchett, \& Busby, 2005; Mehlum et al., 2006). Ultimately, institutions act as intermediary variables between resource abundance and development and they can either moderate or exacerbate the presumed negative relationship between natural resource abundance and economic development (Dietsche, 2007).

How can institutions offer a remedy to the resource curse? An institutional focus on resource dependency primarily relates to good governance and democracy. Democratic countries with considerable natural resources such as the United States, Canada, Norway, and Australia have advanced and diversified economies. These democracies often fare better than their autocratic counterparts because they contain rentseeking behavior by allowing public interests to be represented in the decision making 


\section{Kerem Öge - Transparent Autocracies}

process. For instance, in Norway, Alaska, and Alberta, citizens can counterbalance special interests in the oil industry. In contrast, weak civil societies and non-transparent decision making could facilitate corruption and mismanagement (Eifert, Gelb, \& Tallroth, 2003).

One can argue that components of democracies most relevant to the question of resource dependence are political accountability and civil liberty. Accountability in political institutions "keeps leaders focused on reform and limits their ability to engage in substantial rent seeking” (Deese, 2003, pp. 43-44). Accountable public spending prevents powerful elites from transferring resource revenues to their own accounts (Collier \& Hoeffler, 2009). Accountability gives people an opportunity to participate in the decision making process and removes the temptation on the part of the leaders to hide revenues.

Similarly, civil liberty is an essential part of democracies that can moderate predatory behavior by the political elite. Civic and political associations allow citizens to participate in democratic institutions and bolster a political culture of collectivity (De Tocqueville, 2003). They also lead to more effective governance and democracy (Putnam, 1994). In extractive industries, civil society involvement prevents abuses of power by few individuals at the top and permits more policy options (Hyden, 1997, p. 12).

Interestingly, not all aspects of democracies are potential remedies for developing countries. For example, Collier and Hoeffler (2009) argue that competitive elections in partial democracies could facilitate patronage politics and corruption. Particularly, fear of losing the government can either precipitate or accelerate the expropriation of precious resources by the elite. Similarly, in certain issue areas, such as environmental 


\section{Kerem Öge - Transparent Autocracies}

governance, autocracies could prove to be more efficient in implementing reforms compared to democracies, particularly in the short term (Beeson, 2010; Gilley, 2012; Zhu, Zhang, Ran, \& Mol, 2015). Overall, however, it is clear that democracies have better tools to address challenges of resource abundance, particularly with regards to revenue management.

Focusing on institutions is a dynamic approach to understanding resource dependency, which also indicates a solution to the problem. The presumption is that if all resource-rich countries become liberal democracies then the so-called curse would disappear. However, contrary to the predictions of the modernization theory, the process of democratization is not a guaranteed outcome for developing countries. The modernization theory has long claimed that political development would eventually pursue economic welfare (Lipset, 1959). In other words, countries would become more democratic as their per capita incomes gradually increase (Dahl, 1971; Huntington, 1993). However, later research and experience revealed that while economic development makes democracies survive longer, it does not necessarily transform dictatorships into democracies (Przeworski, Alvarez, Cheibub, \& Limongi, 1996). Democratic reform is often difficult to achieve in these countries since it can dramatically alter the balance of economic power and deprive the privileges of elites that control the economy. Occasionally, leaders of authoritarian countries may implement cosmetic reforms in order to maintain political legitimacy, while they zealously block any political openings (Deese, 2003). In particular, the experience of many authoritarian oil states in the Gulf shows that democratization is not an automatic outcome of rapidly increasing income levels. On the contrary, it has been shown that oil wealth adversely affects 


\section{Kerem Öge - Transparent Autocracies}

democracy (Jensen \& Wantchekon, 2004; Korhonen, 2004) and lengthens authoritarian regimes (Michael L Ross, 2001, 2008).

Aware of the limitations of democracy promotion in authoritarian resource-rich countries, international financial institutions, such as the World Bank and the IMF, have focused on other methods, such as transparency, to improve governance. While transparency is not a solution to all problems of governance (Gupta, 2008, 2010; Gupta \& Mason, 2014) it is a norm that can be easily adopted by a diverse range of governments. Transparency acts as a precipitator, which could lead to better decisions, policies, and processes without causing a fundamental shift in the political regime.

Despite its growing global appeal, transparency lacks a common definition. It is an umbrella term, which can refer to various phenomena including public availability of information on policy-making processes, policy outcomes, institutions, and different forms of data flows. However, even these categories are too broad and a more effective treatment of the concept might require a sectorial approach. In extractive industries, for instance, transparency primarily relates to the way governments manage their natural resources including transparency in government revenues and expenditures, awarding of contracts and licenses, public procurement, politicians' personal wealth, appointments and promotions, clarity of roles and responsibilities, adequacy of internal and external accounting, auditing, and open budget processes (IMF, 2007; Kolstad \& Wiig, 2009, p. 526).

Transparency in these categories would make acts of bribery and embezzlement much riskier in different stages of the resource management. More transparency would also provide good incentives to public officials and initiate a fair selection process for 
Kerem Öge - Transparent Autocracies

public servants. Similarly, accessibility of government policies would improve governance (Islam, 2006) and help democratization since it allows the public to hold politicians accountable for their actions (Kolstad \& Wiig, 2009, p. 529). In contrast, a less transparent institutional environment would encourage misappropriation of wealth and other types of clandestine activities.

Overall, one can argue that transparency is a necessary but not a sufficient condition for better governance. Transparency is likely to improve management of natural resources when there is political accountability and free civil society. In this sense, the EITI is an innovative approach to resource management, which attempts to ensure that civil society groups take an active part in the process.

\section{The Extractive Industries Transparency Initiative}

The EITI is a partnership of states, corporations, and NGOs, which aims to establish a global standard of transparency in natural resource management. Inspired by the work of Revenue Watch and Publish What You Pay, the EITI has been the most influential organization to promote revenue transparency following its launch in 2003 by the UK Department for International Development. The premier adopters of the EITI standard were Nigeria, Azerbaijan, Ghana, and the Kyrgyz Republic. However, the EITI's membership gradually multiplied and as of April 2016, 51 resource-rich countries have voluntarily declared to implement the initiative (EITI, 2013). At the moment, the membership is quite diverse and it includes democracies, partial democracies, and autocracies from Sub-Saharan Africa to North America. The initiative is supported by over 90 major companies and over 90 global investment institutions, which are not bound 


\section{Kerem Öge - Transparent Autocracies}

by the transparency requirements but give either financial or technical assistance to the initiative.

By making resource management more transparent, supporters of the EITI expect improvements in governance and tax collection processes. The EITI process also creates a level-playing field for companies that operate in the resource sector since they are all required to publish their payments. Finally the EITI also provides reliable and accessible information to the public, which would allow citizens to hold their governments and foreign companies accountable (EITI, 2016f).

How does the EITI function? The key initial step is the establishment of a national MSG, which is composed of designated representatives from the government, companies, and civil society groups. The MSG in each country determines how the EITI process progresses. Its main task is the creation of an annual EITI Report in which governments disclose information on tax payments, licenses, contracts, production and other key elements of resource extraction while companies disclose their respective accounts. Next, an independent firm comparatively audits the documents published by the MSG. These reports are publicized on the internet by the EITI and the member government, which allows the public to keep track of essential information on the management of natural resources (EITI, 2016d).

One of the most striking features of the EITI is to include civil society groups as equal partners in the MSG (Søreide \& Truex, 2013). The MSG model is an innovative governance structure, which brings various stakeholders together to work towards implementing a certain policy, solving a common problem, or reaching a common goal. The EITI Standard includes specific measures to make sure that civil society fully and 


\section{Kerem Öge - Transparent Autocracies}

actively participates in the MSG while maintaining its independent status (EITI, 2016c). NGOs in every EITI-implementing country have to actively participate and play key roles in the multi-stakeholder mechanism regardless of the political regime of the member country. NGOs assess individual reports created by the government and the companies and they offer comments and suggestions for improvements and clarifications. They can also raise concerns regarding the overall EITI process and verify that the government complies with its assurances.

The MSG process is likely to function well in democratic regimes, yet it is difficult to replicate this model in non-democracies. On paper, NGOs can participate in the national MSGs in all EITI countries. However, in authoritarian contexts these groups may not have the freedom to raise concerns about the process and act as whistleblowers. The MSG model demands an institutional set-up, which permits political accountability for any discrepancies discovered in the auditing process. ${ }^{2}$ Yet it is often unthinkable for NGOs in authoritarian states to hold politicians or businesses accountable for corruption or mismanagement of revenues without serious repercussions. Furthermore, in many authoritarian resource-rich countries, civil society groups do not have the financial means and technical capacity to monitor resource management.

Since the creation of the EITI, non-democratic countries including Afghanistan, Azerbaijan, Cameroon, Central African Republic (currently suspended), Chad, Democratic Republic of Congo, Republic of the Congo, Equatorial Guinea, Gabon, Iraq, Kazakhstan, Mauritania, Tajikistan, Yemen (currently suspended) have become members to the initiative. Many of these countries have functional national MSGs, which implement the EITI standard by publishing regular reports (EITI, 2014). Yet, lacking

\footnotetext{
${ }^{2}$ Interview with Dr. Francisco Paris, EITI Director, 10 May 2011, Oslo.
} 
Kerem Öge - Transparent Autocracies

basic civil and associational rights, NGOs in these countries have limited capacity and space to perform their key duties in the MSGs (Aaronson, 2011; Freedom House, 2015a; Ölcer, 2009; Scanteam, 2011). In that sense, transparent autocracies are a reality in the context of the extractive industries.

The recent scholarly interest in the EITI focuses on its potential impact on various indicators of governance including transparency, corruption, rule of law, and political accountability (David-Barrett \& Okamura, 2013; Kasekende, Abuka, \& Sarr, 2016; Mejía Acosta, 2013; Öge, 2016a, 2016b; Papyrakis, Rieger, \& Gilberthorpe, 2016; Sovacool \& Andrews, 2015; Sovacool, Walter, Van de Graaf, \& Andrews, 2016). Similarly, several case studies analyze civil society participation in countries such as Nigeria (Keblusek, 2010), Madagascar (Smith, Shepherd, \& Dorward, 2012), Ghana (Ofori \& Lujala, 2015), the Kyrgyz Republic (Furstenberg, 2015), and Uganda (Sturesson \& Zobel, 2015; Wilson \& Van Alstine, 2014). Yet, so far, the curious phenomenon of transparent autocracies is not adequately addressed in the literature. The following sections contribute to the discussion on the merits of transparency in authoritarian contexts, where active civil society is either rare, or non-existent.

\section{Compliance with Civil Society Standards in Authoritarian EITI- Implementing Countries}

The relative ease with which authoritarian countries have complied with the EITI standard is quite intriguing. Understanding leadership preferences on compliance could shed light on why autocracies sometimes make such unlikely commitments. Compliance literature with regards to international treaties and agreements focuses on how norms are adopted by countries via either rational and/or social mechanisms (March \& Olsen, 1984) 


\section{Kerem Öge - Transparent Autocracies}

that determine leadership preferences (Finnemore, 1993; Finnemore \& Sikkink, 1998). Accordingly, before deciding to either comply or defect, leaders evaluate associated costs and benefits of compliance. They comply when the benefits outweigh the costs and defect when the costs become just too high.

In certain cases, this decision becomes more complicated, especially when states desperately need the benefits from compliance but cannot fully afford the costs. In such cases, states could appease international audience by mimicking compliance to certain global norms. As such they combine the "rhetoric and outward appearance of compliance with international standards together with relatively hidden behavioral divergence from such standards" (Walter, 2008, p. 5).

This behavior, also known as mock compliance (Walter, 2008), signifies a decoupling, or a gap between institutionalized policies and substantive outcomes (Meyer \& Rowan, 1977). States, which aspire to signal compliance with global norms as a result of external pressures, sign on to agreements and initiatives without necessarily altering their actual policies (Tilcsik, 2010, p. 1474). The main aim of this practice is gaining global legitimacy while also maintaining the internal flexibility to pursue goals (Meyer \& Rowan, 1977).

Walter (2008) argues that mock compliance is more likely to happen when two conditions are met: strong external pressure for reform and high costs of compliance. Compliance with the EITI, particularly the case of civil society participation in national MSGs, satisfies both criteria in authoritarian countries. Firstly, global actors, including Western countries and donor agencies, exert considerable external pressure for reform in extractive industries and often demand strict compliance with regulations and norms on 


\section{Kerem Öge - Transparent Autocracies}

good governance (Gillies, 2010; O'Neill, Balsiger, \& VanDeveer, 2004). In the last decade, transparency, in particular, has become a globally accepted norm. The World Bank, the IMF, and the G-20 strongly endorse and promote transparency in developing countries. Similarly, multinational companies support transparency to improve their own popular image (Gillies, 2010) since they are often criticized by the Western media and advocacy groups for their operations in developing countries.

In addition, developing resource-rich countries feel the pressure to become EITI members due to substantial potential benefits associated with transparency reforms. These benefits include more creditworthiness in global finance (Simmons, 2001; Walter, 2008, p. 39) and higher global reputation as investment destination (David-Barrett \& Okamura, 2013; Henisz, 2002; Walter, 2008, p. 40). These external pressures and incentives associated with transparency in extractive industries force countries to either formally accept NGOs as major stakeholders in natural resource management, or relinquish all potential gains from compliance.

The second condition, which emphasizes high costs of compliance, also holds for the case of EITI. Acknowledging NGOs as equal partners in national MSGs can have substantial potential costs for autocracies (Berliner, 2014). Authoritarian governments are accustomed to carrying out their commercial interactions in in an opaque and secretive manner. In this context, active participation of local NGOs in the MSG may reveal severe mismanagement of revenues and corruption (Mehlum, Moene, \& Torvik, 2008). Accordingly, the cost of effective civil society involvement in the EITI might be too high for those who benefit the most from secret financial transactions, bribes, embezzlement, etc. Furthermore, active civil society participation may spark up broader demands for 
Kerem Öge - Transparent Autocracies

public involvement in politics, which could cause instability and mass anti-government protests.

External pressures and high costs of compliance complicate the decisions of many authoritarian states and the key question is whether civil society participation in national MSGs deviates from the EITI standard as predicted by the mock compliance theory. To respond to this question, below I evaluate whether Azerbaijan and Kazakhstan comply with the EITI standards when they interact with NGOs in the context of their national MSGs. As resource abundant, authoritarian countries, which have been enthusiastic supporters of the EITI process, these two countries represent ideal case studies to evaluate NGO participation in the EITI process.

\section{EITI and Civil Society in Kazakhstan and Azerbaijan}

\subsection{Political System and Governance of Extractive Industries}

Azerbaijan and Kazakhstan are two energy-rich states in the Caspian region that share a common Soviet past. Both countries are governed by strong presidential regimes, which are "authoritarian", or "not free", according to various indices and reports (Freedom House, 2015a; Polity IV, 2010). In Kazakhstan, President Nursultan Nazarbayev's rule remains uninterrupted since 1991. Similarly, in Azerbaijan, President Ilham Aliyev consolidated his reign since the death of his father in 2003. In both countries, presidents control almost every aspect of the extractive sector without being accountable to their populations. As a consequence, citizens find it difficult to access and influence their government's policies on the management of extractive industries. This centralized control over resources and lack of democratic institutions is a major public concern as it facilitates corruption and rentier mentality (see Table 1). In fact, political systems in both 


\section{Kerem Öge - Transparent Autocracies}

countries are built over extensive patronage networks, where loyalty to the president grants substantial political and economic benefits. (Hoffman, 2000, p. 62).

Table 1 - Selected Economic and Political Indicators for Azerbaijan and Kazakhstan

\begin{tabular}{lcc}
\hline & Azerbaijan & Kazakhstan \\
\hline Population & $9,416,598$ & $17,289,224$ \\
GDP per capita (current US\$) & $7,811.80$ & $14,310.00$ \\
Freedom Score 2014 & Not Free - 6 & Not Free -6 \\
Corruption Perceptions Index Ranking 2014 & $126 / 175$ & $126 / 175$ \\
Fuel exports \% of merchandise exports & $93 \%$ & $82 \%$ \\
Extractive sector \% of fiscal revenues & $74 \%$ & $39 \%$ \\
Extractive sector \% of GDP & $47 \%$ & $33 \%$ \\
\hline
\end{tabular}

Notes: All the figures are for 2013 unless otherwise stated. Freedom Score is an index of political rights and civil liberties with 1 representing the most free and 7 the least free.

Sources: (CIA, 2014; Freedom House, 2015a; Revenue Watch, 2013; Transparency International, 2014; World Bank, 2014a, 2014b)

In both countries, civil society groups face numerous difficulties. In Kazakhstan, civil society is actually more vibrant compared to the rest of the region (Saycon, 2014). However, the recent increase in the number of NGOs in this Central Asian state is not necessarily an indicator of genuine civil society activity (Heinrich, 2010, pp. 38-39; Luong \& Weinthal, 1999). Independent NGOs based in Almaty and Astana are closely monitored by the state and they are subject to regular inspections (Dave, 2007, pp. 335336; Freedom House, 2015b). Restrictions on freedom of speech silence many NGOs while state controlled media dictates public opinion (Amnesty International, 2016; Savchenko, 2015). ${ }^{3}$

Furthermore, in the last decade, the government of Kazakhstan has begun to limit the financial contributions of external donors to domestic NGOs. As a result, the number

\footnotetext{
${ }^{3}$ Interview with Dr. Altay Mussurov and Prof. John Dixon, KIMEP University, 22 June 2010, Almaty. Interview with Meruert Makhmutova, director, Public Policy Research Center, 21 June 2010, Almaty.
} 


\section{Kerem Öge - Transparent Autocracies}

of Government Organized NGOs has skyrocketed in the country. As one interviewee indicates: "In the past, NGOs were funded by international finance. Now, government funds and co-opts NGOs." ${ }^{, 4}$ Similarly, most research centers are government funded and they are not in a position to provide independent views. ${ }^{5}$

Overall, there is a lack of genuine interaction between civil society organizations in Kazakhstan and the public at large. Lyaziza Sabyrova, from the Almaty based governance think tank RAKURS, claims that her organization has practical influence, while also conceding that civil society has become weaker over time. The majority of NGOs have fewer than ten members, and successful NGOs sometimes split into different units as they compete for funds from abroad until they are reduced to the level of the individual. $^{6}$

Civil society groups in Azerbaijan face similar challenges. Primarily, there are very few financial resources for NGOs in the country, and it is almost impossible for them to function independently. Furthermore, despite guarantees to the right of association in the constitution, civil society groups in Azerbaijan face very tough registration rules (Sabit Bagirov, 2007) and the government officials deny registration applications without clear explanations (S Bagirov, Ahmedov, \& Tsalik, 2003, pp. 98-100; OSCE, 2002). As a result, the government either directly or indirectly controls most of the registered NGOs. ${ }^{7}$ Interestingly, in both countries civil society groups were influential actors during the founding phase of the EITI. However, the political environment in Kazakhstan and

\footnotetext{
${ }^{4}$ Interview with Pavel Lobachev, director, ECHO, 24 June 2010 in Almaty.

${ }^{5}$ Interview with Lyaziza Sabyrova, director, RAKURS 23 June 2010, Almaty.

${ }^{6}$ Interview with Lyaziza Sabyrova, director, RAKURS 23 June 2010, Almaty.

${ }^{7}$ Interview with Kenan Aslanli, expert, Public Finance Monitoring Center, 9 June 2010, Baku. Interview with Sabit Bagirov, a member of the EITI Council, the director of the FAR Centre, and the former president of SOCAR, 18 June 2010, Baku. Interview with Azer Mehdiyev (chairman) and Rovshen Agayev (expert in economics) of the Support for Economic Initiatives Public Union, 14 June 2010, Baku.
} 
Kerem Öge - Transparent Autocracies

Azerbaijan severely restricts the capacity of civil society groups to carry out their monitoring and whistle-blowing functions as envisaged by the EITI. Hence, NGO participation in the subsequent multi-stakeholder process is not satisfactory.

\subsection{Civil Society Groups and the EITI Process}

The EITI membership of two countries progressed in different speeds. While Azerbaijan became one of the first implementing countries, in Kazakhstan the initiative advanced at a slower pace. Nevertheless, both governments' attitudes to civil society participation show remarkable similarities.

As a substantial exporter of oil, Kazakhstan expressed its interest in the EITI as early as 2003 (PPRC, 2005). In this period, NGOs from Kazakhstan, including the local chapter of Soros Foundation, carried out numerous capacity-building initiatives to better understand revenue transparency. ${ }^{8}$ In 2004, several leading civil society activists, including Pavel Lobachev of ECHO, created the coalition of NGOs for the EITI with assistance from the World Bank, the British Council, Publish What You Pay, Revenue Watch, and the Soros Foundation. The coalition quickly attracted interest from more than 60 NGOs and established representation in fourteen regions and two cities. ${ }^{9}$

Eventually, in June 2005, President Nazarbayev personally announced his support for the EITI at the International Business Conference of the Asia Society and the membership process officially commenced (PPRC, 2005, p. 14). Interestingly, despite endorsing the EITI, the Kazakh government hesitated to include civil society as an equal partner in the national MSG. Particularly, the energy minister in 2005, Vladimir Shkolnik, prevented NGOs from accessing key information on contracts and revenues

\footnotetext{
${ }^{8}$ Interview with Anton Artemyev, exective director, Soros Foundation, 02 July 2010, Astana.

${ }^{9}$ Interview with Pavel Lobachev, director, ECHO, 24 June 2010 in Almaty.
} 


\section{Kerem Öge - Transparent Autocracies}

due to concerns about confidentiality (PPRC, 2005, p. 19). In the end, the NGO coalition signed the memorandum on the establishment of a National Stakeholder's Council (ICG, 2007, p. 25), which ensured the participation of civil society groups in the process. Yet, individual reports from the government and oil companies remained confidential in the EITI framework.

Though Kazakhstan joined the EITI in 2005, for the next two years the country failed to disclose revenues from foreign operators and prevented the NGO coalition to participate in the process as envisaged. Kazakhstan published its first EITI report in January 2008 (Linn, 2009) and since then the Kazakh MSG has been producing annual reports, which provide a comprehensive overview of the extractive industry in the country. Eventually, Kazakhstan achieved a compliant member status in October 2013 and became the first EITI country to publish data from 2014 (EITI, 2016b), At the moment, the government of Kazakhstan makes an effort to disseminate its EITI reports to the public by publishing a popular, simplified version on its website (EITI, 2016e).

Despite these positive outcomes, civil society groups are not confident about their future prospects in the EITI process. ${ }^{10}$ Officials often limit the actions of NGOs working on revenue transparency due to secrecy surrounding oil contracts. ${ }^{11}$ Furthermore, a new law on NGOs, approved in December 2015 despite protests from more than 50 organizations, restricts the ability of the civil society to freely access grants from nongovernmental institutions and donors. The law establishes a single state operator, which controls NGO funding, and gives the state a veto over 'undesirable' NGOs and their

\footnotetext{
${ }^{10}$ Interview with Pavel Lobachev, director, ECHO, 24 June 2010 in Almaty. Interview with Lyaziza Sabyrova, director, RAKURS 23 June 2010, Almaty. Interview with Janar Jandossova, director, SANGE Research Center, 29 June 2010, Astana.

${ }^{11}$ Interview with Dr. Altay Mussurov and Dr. John Dixon, KIMEP University, 22 June 2010, Almaty.
} 
Kerem Öge - Transparent Autocracies

activities (Lillis, 2015). NGOs believe that these new rules are likely to damage the EITI process. In addition to this restrictive legislation, the recent crackdown on peaceful protests against government's land reform proposals reveals a certain degree of intolerance to consensual politics by the Kazakh government (HRW, 2016).

Compared to Kazakhstan, the government of Azerbaijan was more eager to take part in the EITI under the direction of the former president Heydar Aliyev. Consequently, Azerbaijan committed to the EITI at its first summit in 2003. The ailing president endorsed the EITI to improve his country's international prestige and secure the support of international oil companies operating in the country (Akiner, 2004, pp. 378-379). The World Bank officially endorsed the EITI process in Azerbaijan, and Revenue Watch and Open Society Institute helped organize a civil society coalition in favor of the initiative.

Reminiscent of the process in Kazakhstan, the Azerbaijan government was skeptical of NGO involvement in the MSG, despite the fact that civil society participation is a key component of the initiative (Asadov, 2009, p. 97). Eventually, the government, companies, and the domestic NGO coalition agreed to sign the EITI memorandum of understanding in 2004 and Azerbaijan became the first ever fully compliant country in 2009.

Many interviewees from the civil society and the government agree on the significance of the initiative, which for the first time in Azerbaijan allowed the norm of transparency to be endorsed at the national level (SOFAZ, 2007). Ferda Asadov, executive director of the Open Society Institute-Azerbaijan (OSI-AZ), applauds the EITI structure for its inclusion of civil society via the MSG (Asadov, 2009). ${ }^{12}$ In a similar tone, NGO representatives emphasize the unique nature of their participation in the EITI,

\footnotetext{
${ }^{12}$ Interview with Ferda Asadov, Executive Director, OSI-AZ, 7 June 2010, Baku.
} 


\section{Kerem Öge - Transparent Autocracies}

which is the only obligation of the government to interact with civil society in Azerbaijan (Gahramanova, 2009). ${ }^{13}$ The experts at the State Oil Fund of the Republic of Azerbaijan (SOFAZ) embrace the EITI as the first initiative that brought together all three parties and they expect that the NGOs should be satisfied with the result. Accordingly, the Azerbaijani NGOs actively participate in the EITI process through meetings and the preparation of reports: 'The whole process functions through their participation'. ${ }^{14}$

At the same time, various interviewees are concerned about the monitoring capabilities of NGOs in Azerbaijan, where the civil society is quite weak. Furthermore, despite the official stance of the government, which tolerates NGO participation, not all sections of the civil society are actually represented in the MSG. Independent NGOs, in particular, are often ignored and excluded from discussions. Many interviewees also claim that the Azerbaijan implements the EITI specifically for reputational purposes. As a result, the EITI process is unlikely to have any positive spillover effects on political and civil rights. $^{15}$

The success of transparency promotion depends on the ability of civil society groups to fully perform their monitoring functions. Given the space to operate, civil society groups in Azerbaijan are able to help improve resource management. For example, the EITI-Azerbaijan coalition of civil society institutions has issued complaints about the costs and the time horizon of the Azeri-Chirac-Guneshli (ACG) project of oil

\footnotetext{
${ }^{13}$ Interview with Fidan Najafova, Programme Director for Transparency of Oil Revenues and Public Finance, OSI-AZ, 7 June 2010, Baku.

${ }^{14}$ Interview with Farid Farzaliyev, Head of the EITI Secretariat, SOFAZ, 18 June 2010, Baku.

15 Interview with Kenan Aslanli, expert, Public Finance Monitoring Center, 9 June 2010, Baku. Interview with Azer Mehdiyev (chairman) and Rovshen Agayev (expert in economics) of the Support for Economic Initiatives Public Union, 14 June 2010, Baku. Interview with Fidan Najafova, Programme Director for Transparency of Oil Revenues and Public Finance, OSI-AZ, 7 June 2010, Baku. Interview with Ingilab Ahmedov, member of the institutional board of EITI-Azerbaijan, 16 June 2010, Baku.
} 


\section{Kerem Öge - Transparent Autocracies}

production, which have significantly passed projections (Kalyuzhnova \& Bluth, 2008, pp. 186-187).

Unfortunately, the civil society environment in Azerbaijan severely deteriorated since the interviews were conducted in 2010. Particularly, the human rights protests in Baku following the Arab Spring initiated a major government crackdown against human rights groups, journalists, and NGOs in 2012. The subsequent period saw detention, conviction, and harassment of hundreds of activists (Human Rights Watch, 2013). Furthermore, the legislative amendments in 2013 allowed the Azerbaijani government to restrict and control the funding source of all NGOs in the country. As a consequence, NGOs increasingly feel constrained in their ability to participate in the EITI process. Specifically, civil society groups find it extremely difficult to access funding, organize EITI-related events and raise concerns regarding the management of the natural resource sector (NRGI, 2014).

In 2015, a fact finding mission led by the then-EITI Chair Clare Short confirmed the substantial limitations of civil society in Azerbaijan and as a consequence, the EITI board downgraded Azerbaijan's status from compliant to candidate in April (EITI, 2016a). The EITI board expects Azerbaijan to ensure that civil society groups participate in the MSG in a meaningful way before restoring its compliant status.

The decision of the EITI Board is a major blow to Azerbaijan's reputation (Eurasia.net, 2015). It is particularly damaging during a period of low oil prices, which severely harms the economy and creates an urgent need for loans and investment. In this context, in order to restore investor confidence, the country has scaled back its 


\section{Kerem Öge - Transparent Autocracies}

crackdown and has released 17 journalists and activists since March (Financial Times, 2016).

Overall, in both Azerbaijan and Kazakhstan, the EITI process was a major opportunity for civil society groups and they made an important effort to be officially recognized by the government. At least in theory, the EITI has provided a legitimate medium for civil society groups to converse with their governments and the companies on natural resource management. Reluctantly, both governments had to agree to NGO participation in the MSG, or risked losing potential benefits associated with EITI membership.

Azerbaijan and Kazakhstan continue to publish EITI reports, hence implement transparency in resource revenues. However, their compliance in this sense does not signify a willingness to make civil society an equal partner in resource management. On the contrary, governments of Kazakhstan and Azerbaijan did not hesitate to crackdown on independent civil society organizations following the Arab Spring and revolutions in Ukraine and the Kyrgyz Republic. At the moment, both governments are eager to control and co-opt NGOs, block their financial sources, and make their registration process much more difficult. While on paper civil society groups are part of the MSG, in practice independent NGOs find it more and more difficult to exercise their monitoring and whistleblowing capacities due to political, technical, financial, and bureaucratic constraints. This outcome partially supports the mock compliance argument, which underlines a decoupling between international commitments and actual practices. Even if the EITI process granted certain NGO groups unprecedented access to the natural 


\section{Kerem Öge - Transparent Autocracies}

resource management process, the governments did not have any intention to allow independent monitoring and scrutiny.

Overall, eager to improve their image and signal openness for material benefits, Azerbaijan and Kazakhstan signed on to the EITI without necessarily liberalizing their natural resource management. Furthermore, despite the underlying rhetoric of more openness and democracy, civil and associational rights have not actually improved in the last 10 years (Freedom House, 2015a; World Bank, 2013). ${ }^{16}$ The following section extends this analysis to all authoritarian EITI members and focuses on trends in civil and associational liberties before and after EITI membership.

\section{Interrupted Time Series Analysis}

The International Secretariat of the EITI does not actively promote democracy and civil rights in member countries. Nevertheless, the overall civil society environment in a country is an indicator of a government's intention to tolerate independent NGOs and civil society participation is a key aspect of the initiative. The EITI Board supports domestic civil society groups so that they can improve monitoring and hold the government accountable. As seen in the case of Azerbaijan, the Board can implement sanctions when NGOs cannot fully function in an EITI-implementing country. As such, the EITI process is directly related to civil and associational rights.

In this section, I use an interrupted time series (ITS) design to analyze the relationship between EITI membership and civil and associational liberties, in order to evaluate whether EITI membership correlates with better democratic rights for civil

\footnotetext{
${ }^{16}$ Interview with Fuad Suleymanov, Programme Director, OSI-AZ, 7 June 2010, Baku.
} 


\section{Kerem Öge - Transparent Autocracies}

society groups. In line with the purposes of this paper, I limit the sample of countries to non-democratic governments. ${ }^{17}$

ITS analyzes the causal impact of an intervention (Lewis-Beck \& Alford, 1980; Linden, 2015). It compares observations on two sides a cutoff point to detect any changes in the dependent variable, which could be initiated by this intervention. In this case, the intervention is the first year of EITI membership. However, since the actual year of membership is different for each EITI-implementing state, there is no straightforward way to test the impact of EITI on civil and associational liberties across cases. I create the variable TIME, which is a running count of integers, to resolve this issue. The variable takes the value " 1 " the year a country becomes a member and increases by one every year. The count also goes backwards in order to capture trends in civil and associational liberties before membership. Defined as such, TIME allows us to observe any significant changes in governance trends, or interruptions, in countries before and after EITI membership.

The analysis focuses on the impact of EITI membership on two different dependent variables (DVs) that indicate civil and associational rights. For civil rights $(C I V R I G)$ and associational and organizational rights $(A S S O C R I G)$, I use respective indices by the Freedom House (2015a), which are on a scale of 1 to 7 where 1 indicates the highest degree of freedom. The regression equation for each ITS design is expressed as follows (Linden \& Adams, 2011; Simonton, 1977):

$$
D V_{\mathrm{t}}=\beta_{0}+\beta_{1} T I M E_{\mathrm{t}}+\beta_{2} M E M B E R_{\mathrm{t}}+\beta_{3} T I M E_{\mathrm{t}} M E M B E R_{\mathrm{t}}+\varepsilon_{\mathrm{t}}
$$

\footnotetext{
${ }^{17}$ Non-democratic EITI-implementing countries include Afghanistan, Azerbaijan, Cameroon, Central African Republic, Chad, Democratic Republic of Congo, Republic of Congo, Equatorial Guinea, Gabon, Iraq, Kazakhstan, Mauritania, Tajikistan, and Yemen.
} 
Kerem Öge - Transparent Autocracies

$D V$ indicates the dependent variables and TIME is a running count of integers as explained above. $M E M B E R$ is a dummy variable, which takes the value "1" if a country is an EITI member in a given year and "0" otherwise. By default, the model also includes an interaction of TIME and MEMBER. The coefficient of $\operatorname{MEMBER}\left(\beta_{2}\right)$ indicates the change in the DV immediately after the intervention. The coefficient of the interaction variable $\left(\beta_{3}\right)$ represents the difference in the slope of the outcome variable before and after the intervention, hence reflects longer-term trends. Table 2 shows the outcome of the OLS-regressions based on the ITS model.

Table 2 - EITI Membership and Civil and Associational Rights

\begin{tabular}{lcc}
\hline Variables & CIV RIG & ASSOC RIG \\
\hline TIME & 0.075 & -0.0751 \\
& $(-2.02)$ & $(-0.96)$ \\
& & \\
MEMBER & -0.0787 & -0.123 \\
& $(-0.86)$ & $(-0.48)$ \\
INTERACTION & 0.0172 & -0.208 \\
& $(-0.3)$ & $(-1.75)$ \\
\hline $\mathbf{N}$ & & \\
\hline
\end{tabular}

Note: $\mathrm{t}$ statistics in parentheses. $\mathrm{P}$ values (p) test the null hypothesis that the coefficient is equal to zero. A low p-value $(<0.05)$ indicates that the coefficient is statistically significant (identified by asterisks). $* \mathrm{p}<0.05 ; * * \mathrm{p}<0.01 ; * * * \mathrm{p}<0.001$

The results show that EITI membership is not significantly correlated with any changes in the dependent variables. This outcome supports the narrative from the case studies. In both Azerbaijan and Kazakhstan, despite the initial euphoria regarding civil society participation in the EITI, the oppressive political environment has endured after membership. In many authoritarian EITI-implementing countries, civil society groups 


\section{Kerem Öge - Transparent Autocracies}

face substantial problems and independent NGOs are limited in their ability to interact with the government. Furthermore, the multi-stakeholder method, which is an experiment in consensual politics, did not spill over to other areas of citizens' participation in politics. Along with the case studies presented in this paper, which show that civil society participation in authoritarian EITI-implementing countries deviates significantly from the EITI standards, these results suggest that civil society groups remain the weakest link in the national MSGs.

\section{Conclusion}

The EITI is a pragmatic approach to improving resource management in extractive industries and it relies on active civil society participation to ensure that citizens' interests are represented in the decision making process. As such, the case of authoritarian EITIimplementing countries presents a curious situation where autocrats have to acknowledge the existence of domestic NGOs and grant them access to the complete resource value chain. In certain ways, the EITI process in authoritarian states contributed to the mobilization of non-governmental organizations (NGOs) that focus on resource management and the initiative provided certain NGOs unprecedented access to the government. However, the qualitative and the quantitative analyses in this paper underline substantial problems related to civil society participation in the national MSGs in authoritarian countries. Ongoing repression in these countries prevents NGOs from adequately monitoring resource management and contributing to policy-making. Even if authoritarian EITI-implementing countries agree to include civil society groups as equal partners, in practice these groups are often sidelined, co-opted, silenced, or harassed by 


\section{Kerem Öge - Transparent Autocracies}

the government. Despite expectations, the EITI membership is not associated with higher levels of civil and associational liberties.

Even if authoritarian leaders are attracted to the reputational benefits of the EITI, they also often consider civil society participation in the MSG as a major political cost. If autocrats feel that increased civil society activism poses a threat to the survival of their regime, they might forgo the associated benefits of EITI membership. In the end, the most important challenge for the initiative is to ensure that civil society remains an equal partner in the EITI process even in authoritarian countries. This is a difficult task and it requires a delicate strategy where the EITI International Secretariat continues to defend the active involvement of NGOs in national MSGs without jeopardizing the whole process as seen in the case of Azerbaijan. 


\section{Bibliography}

Aaronson, Susan Ariel. (2011). Limited partnership: Business, government, civil society, and the public in the Extractive Industries Transparency Initiative (EITI). Public Administration and Development, 31(1), 50-63.

Akiner, S. (2004). Ten years on: achievements, new concerns, future prospects. In S. Akiner (Ed.), The Caspian: Politics, Energy and Security (pp. 365-399). New York: Routledge.

Amnesty International. (2016). Kazakhstan 2015/2016. Retrieved 11/11, 2016, from https://http://www.amnesty.org/en/countries/europe-and-centralasia/kazakhstan/report-kazakhstan/

Asadov, F. (2009). The Public oversight of oil projects in Azerbaijan. Oxford: Blackwell Publishing UNESCO.

Auty, RM. (1993). Sustaining development in mineral economies: The resource curse thesis. New York: Routledge.

Bagirov, S, Ahmedov, I, \& Tsalik, S. (2003). State Oil Fund of the Azerbaijan Republic. In S. Tsalik (Ed.), Caspian Oil Windfalls: Who will benefit? New York: Caspian Revenue Watch Open Society Institue.

Bagirov, Sabit. (2007). Azerbaijani Oil: Revenues, Expenses and Risks. Baku: EITI-AZ.

Beeson, Mark. (2010). The coming of environmental authoritarianism. Environmental Politics, 19(2), 276-294.

Berliner, Daniel. (2014). The political origins of transparency. The Journal of Politics, 76(02), 479-491.

Bruno, M, \& Sachs, J. (1982). Energy and Resource Allocation: A Dynamic Model of the" Dutch Disease". The Review of Economic Studies, 49(5), 845-859.

CIA. (2014). The World Factbook. Retrieved 02/23, 2015, from https://http://www.cia.gov/library/publications/the-world-factbook/

Collier, P., \& Hoeffler, A. (2009). Testing the neocon agenda: Democracy in resourcerich societies. European Economic Review, 53(3), 293-308.

Dahl, Robert Allen. (1971). Polyarchy: Participation and opposition. New Haven: Yale University Press.

Dave, B. (2007). Kazakhstan. In J. Goehring (Ed.), Nations in transit 2007: democratization from Central Europe to Eurasia (pp. 325-348). Hungary: Freedom House.

David-Barrett, Liz, \& Okamura, Ken. (2013). The transparency paradox: why do corrupt countries join EITI. ERCAS, Working Paper No.38.

De Tocqueville, A. (2003). Democracy in America. Washington D.C.: Regnery Publishing.

Deese, David A. (2003). From Executive Crafting to Pluralistic Politics: Political and Economic Reform as Sequential, Cumulative Processes in Developing States. In S. Ramaswamy \& J. Cason (Eds.), Development and Democracy: New Perspectives on an Old Debate (pp. 43-68). Hanover: University Press of New England.

Dietsche, E. (2007). The quality of institutions: A cure for the 'resource curse'? Oxford Policy Institute. 
Kerem Öge - Transparent Autocracies

Eifert, B, Gelb, A, \& Tallroth, NB. (2003). The political economy of fiscal policy and economic management in oil exporting countries. In J. Davis, R. Ossowski \& A. Fedelino (Eds.), Fiscal policy formulation and implementation in oil-producing countries (pp. 82-122). Washington D.C.: International Monetary Fund.

EITI. (2013). The EITI Standard. Retrieved 10/26, 2014, from https://eiti.org/files/English_EITI\%20STANDARD_11July_0.pdf

EITI. (2014). EITI Countries. Retrieved 11/3, 2014, from https://eiti.org/countries

EITI. (2016a). EITI Azerbaijan. Retrieved 08/12, 2016, from https://eiti.org/implementing_country/35

EITI. (2016b). EITI Kazakhstan. Retrieved 08/11, 2016, from https://eiti.org/implementing_country/24

EITI. (2016c). The EITI Standard 2016. Retrieved 08/24, 2016, from https://eiti.org/sites/default/files/migrated_files/english_eiti_standard_0.pdf

EITI. (2016d). How we work. Retrieved 08/17, 2016, from https://eiti.org/about/howwe-work

EITI. (2016e). Kazakhstan takes the lead on timely EITI reporting. Retrieved 08/11, 2016, from https://eiti.org/node/4445

EITI. (2016f). Who we are. Retrieved 08/17, 2016, from https://eiti.org/about/who-weare

Eurasia.net. (2015). Azerbaijan: EITI Downgrade Dents Baku's Image. Retrieved 11/11, 2016, from http://www.eurasianet.org/node/72986

Financial Times. (2016). Azerbaijan: Aiming to Please. Retrieved 11/11, 2016, from https://http://www.ft.com/content/d89d55ae-6b73-11e6-a0b1-d87a9fea034f

Finnemore, Martha. (1993). International organizations as teachers of norms: the United Nations Educational, Scientific, and Cutural Organization and science policy. International Organization, 565-597.

Finnemore, Martha, \& Sikkink, Kathryn. (1998). International norm dynamics and political change. International Organization, 52(04), 887-917.

Freedom House. (2015a). Freedom in the World 2015. Retrieved 02/23, 2015, from https://freedomhouse.org/report/freedom-world/freedom-world2015\#.VOteZ3Y0fP4

Freedom House. (2015b). Kazakhstan. Retrieved 11/11, 2016, from https://freedomhouse.org/report/nations-transit/2015/kazakhstan

Furstenberg, Saipira. (2015). Consolidating global governance in nondemocratic countries: Critical reflections on the Extractive Industries Transparency Initiative (EITI) in Kyrgyzstan. The Extractive Industries and Society, 2(3), 462-471.

Gahramanova, Aytan. (2009). Internal and external factors in the democratization of Azerbaijan. Democratization, 16(4), 777-803.

Gilley, Bruce. (2012). Authoritarian environmentalism and China's response to climate change. Environmental Politics, 21(2), 287-307.

Gillies, A. (2010). Reputational concerns and the emergence of oil sector transparency as an international norm. International Studies Quarterly, 54(1), 103-126.

Gupta, Aarti. (2008). Transparency under scrutiny: Information disclosure in global environmental governance. Global Environmental Politics, 8(2), 1-7.

Gupta, Aarti. (2010). Transparency in global environmental governance: a coming of age? Global Environmental Politics, 10(3), 1-9. 
Kerem Öge - Transparent Autocracies

Gupta, Aarti, \& Mason, Michael. (2014). Transparency in Global Environmental Governance: Critical Perspectives: MIT Press.

Heinrich, A. (2010). The formal political system in Azerbaijan and Kazakhstan: A background study: Forschungsstelle Osteuropa an der Universitat Bremen.

Henisz, Witold J. (2002). The institutional environment for infrastructure investment. Industrial and corporate change, 11(2), 355-389.

Hoffman, DI. (2000). Azerbaijan: The Politicization of Oil. In R. Ebel \& R. Menon (Eds.), Energy and Conflict in Central Asia and the Caucasus (pp. 55-78). Lanham: Rowman and Littlefield Publishers.

HRW. (2016). Kazakhstan: Crackdown on Peaceful Protest. Retrieved 08/12, 2016, from https://http://www.hrw.org/news/2016/05/23/kazakhstan-crackdownpeaceful-protest

Human Rights Watch. (2013). Tightening the Screws. Retrieved 11/11, 2016, from https://http://www.hrw.org/report/2013/09/01/tightening-screws/azerbaijanscrackdown-civil-society-and-dissent

Huntington, Samuel P. (1993). The third wave: Democratization in the late twentieth century. Norman: University of Oklahoma Press.

Hyden, G. (1997). Civil society, social capital, and development: Dissection of a complex discourse. Studies in Comparative International Development (SCID), 32(1), 330 .

ICG. (2007). Central Asia's Energy Risks: International Crisis Group.

IMF. (2007). Guide on Resource Revenue Transparency. Retrieved 03/20, 2015, from https://http://www.imf.org/external/np/pp/2007/eng/101907g.pdf

Isham, J., Woolcock, M., Pritchett, L., \& Busby, G. (2005). The varieties of resource experience: natural resource export structures and the political economy of economic growth. The World Bank Economic Review, 19(2), 141-174.

Islam, Roumeen. (2006). Does more transparency go along with better governance? Economics \& Politics, 18(2), 121-167.

Jensen, Nathan, \& Wantchekon, Leonard. (2004). Resource wealth and political regimes in Africa. Comparative Political Studies, 37(7), 816-841.

Kalyuzhnova, Yelena, \& Bluth, Christoph. (2008). Economics of the Caspian Oil and Gas Wealth: Companies, Governments, Policies. New York: Palgrave McMillan.

Karl, T.L. (1997). The paradox of plenty: Oil booms and petro-states. Berkeley and Los Angeles: University of California Press.

Kasekende, Elizabeth, Abuka, Charles, \& Sarr, Mare. (2016). Extractive industries and corruption: Investigating the effectiveness of EITI as a scrutiny mechanism. Resources Policy, 48, 117-128.

Keblusek, Mary Ella. (2010). Is EITI really helping improve global good governance?

Kolstad, Ivar, \& Wiig, Arne. (2009). Is transparency the key to reducing corruption in resource-rich countries? World Development, 37(3), 521-532.

Korhonen, Iikka. (2004). Does democracy cure a resource curse? BOFIT-Institute for Economies in Transition Bank of Finland, BOFIT Discussion Papers 18/ 2004.

Lewis-Beck, Michael S, \& Alford, John R. (1980). Can government regulate safety? The coal mine example. American Political Science Review, 74(03), 745-756.

Lillis, Joanna (2015). Kazakhstan: NGO Law Approved Amid Civil Society Resistance. Retrieved 08/12, 2016, from http://www.eurasianet.org/node/76366 
Kerem Öge - Transparent Autocracies

Linden, Ariel. (2015). Conducting interrupted time-series analysis for single-and multiple-group comparisons. Stata Journal, 15(2), 480-500.

Linden, Ariel, \& Adams, John L. (2011). Applying a propensity score-based weighting model to interrupted time series data: improving causal inference in programme evaluation. Journal of evaluation in clinical practice, 17(6), 1231-1238.

Linn, J. F. (2009). Central Asia's Energy Challenge: Overcoming the Natural Resource Curse. from Brookings Institution

Lipset, Seymour Martin. (1959). Some social requisites of democracy: Economic development and political legitimacy. The American Political Science Review, 53(1), 69-105.

Luong, P.J., \& Weinthal, E. (1999). The NGO paradox: democratic goals and nondemocratic outcomes in Kazakhstan. Europe-Asia Studies, 51(7), 1267-1284.

Luong, P.J., \& Weinthal, E. (2010). Oil is not a curse: Ownership structure and institutions in soviet successor states. Cambridge: Cambridge University Press.

March, James G., \& Olsen, Johan P. (1984). The New Institutionalism: Organizational Factors in Political Life. American Political Science Review, 78, 734-749.

Mehlum, Halvor, Moene, Karl, \& Torvik, Ragnar. (2006). Institutions and the Resource Curse. The Economic Journal, 116(508), 1-20.

Mehlum, Halvor, Moene, Karl, \& Torvik, Ragnar. (2008). Mineral rents and social development in Norway., Prepared for UNRISD project on Financing Social Policy in Mineral-Rich Countries. Geneva.

Mejía Acosta, Andrés. (2013). The impact and effectiveness of accountability and transparency initiatives: The governance of natural resources. Development Policy Review, 31(s1), s89-s105.

Meyer, John W., \& Rowan, Brian. (1977). Institutionalized organizations: Formal structure as myth and ceremony. American journal of sociology, 83(2), 340.

NRGI. (2014). EITI Reacts to Civil Society Situation in Azerbaijan. Retrieved 08/12, 2016, from http://www.resourcegovernance.org/blog/eiti-reacts-civil-societysituation-azerbaijan

O'Neill, Kate, Balsiger, Jörg, \& VanDeveer, Stacy D. (2004). Actors, norms, and impact: Recent international cooperation theory and the influence of the agent-structure debate. Annu. Rev. Polit. Sci., 7, 149-175.

Ofori, Jerome Jeffison Yaw, \& Lujala, Päivi. (2015). Illusionary Transparency? Oil Revenues, Information Disclosure, and Transparency. Society \& Natural Resources, 28(11), 1187-1202.

Öge, Kerem. (2016a). To Disclose or not to Disclose: How Global Competition for Foreign Direct Investment Influences Transparency Reforms in Extractive Industries. Energy Policy, Forthcoming.

Öge, Kerem. (2016b). Which transparency matters? Compliance with anti-corruption efforts in extractive industries. Resources Policy, 49, 41-50.

Ölcer, Dilan. (2009). Extracting the Maximum from the EITI. OECD Development Centre Working Paper No.276. Retrieved 03/24, 2015, from http://www.oecd.org/dev/42342311.pdf

OSCE. (2002). Problems of NGO Registration in Azerbaijan. Baku. 
Kerem Öge - Transparent Autocracies

Papyrakis, Elissaios, Rieger, Matthias, \& Gilberthorpe, Emma. (2016). Corruption and the extractive industries transparency initiative. The Journal of Development Studies, 1-15.

Polity IV. (2010). $\quad$ Retrieved 09/08, 2012, from http://www.systemicpeace.org/polity/polity4.htm

PPRC. (2005). Implementation of Extractive Industries Transparency Initiative in Kazakhstan: problems and prospects: Public Policy Research Center.

Przeworski, A, Alvarez, M, Cheibub, JA, \& Limongi, F. (1996). What makes democracies endure? Journal of democracy, 7, 39-55.

Putnam, RD. (1994). Making democracy work: Civic traditions in modern Italy. Princeton: Princeton University Press.

Revenue Watch. (2013). Resource Governance Index. Retrieved 12/02, 2013, from http://www.revenuewatch.org/rgi

Robinson, J.A., Torvik, R., \& Verdier, T. (2006). Political foundations of the resource curse. Journal of Development Economics, 79(2), 447-468.

Ross, M.L. (1999). The political economy of the resource curse. World Politics, 51(2), 297-322.

Ross, Michael L. (2001). Does oil hinder democracy? World Politics, 53(3), 325-361.

Ross, Michael L. (2008). But seriously: Does oil really hinder democracy? UCLA Department of Political Science: mimeo.

Sachs, J. D., \& Warner, A. M. (1995). Natural resource abundance and economic growth (Vol. Working Paper 5398, pp. 1-47): National Bureau of Economic Research.

Sala-i-Martin, X., \& Subramanian, A. (2003). Addressing the natural resource curse: an illustration from Nigeria. NBER Working Paper.

Savchenko, Katerina. (2015). Report: The harassment of civil society in Kazakhstan. Open Dialog. Retrieved 11/11, 2016, from http://en.odfoundation.eu/a/6629, report-the-harassment-of-civil-society-inkazakhstan

Saycon, Mike. (2014). A bright future for Kazakhstan's NGOs. Retrieved 08-11, 2016, from https://http://www.theguardian.com/global-development-professionalsnetwork/2014/jun/02/kazkahstan-civil-society-challenge-soviet

Scanteam. (2011). Achievements and Strategic Options: Evaluation of the Extractive Industries Transparency Initiative. Retrieved 12/14, 2015, from https://eiti.org/files/2011-EITI-evaluation-report.pdf

Simmons, Beth A. (2001). The international politics of harmonization: The case of capital market regulation. International Organization, 55(03), 589-620.

Simonton, Dean K. (1977). Cross-sectional time-series experiments: Some suggested statistical analyses. Psychological Bulletin, 84(3), 489.

Smith, Shirley M, Shepherd, Derek D, \& Dorward, Peter T. (2012). Perspectives on community representation within the Extractive Industries Transparency Initiative: Experiences from south-east Madagascar. Resources Policy, 37(2), 241-250.

SOFAZ. (2007). The UN Public Service Award handed out to the State Oil Fund of Azerbaijan. $\quad$ Retrieved 05.24, 2012, from http://www.oilfund.az/en_US/news/358/100/The-UN-Public-Service-Awardhanded-out-to-the-State-Oil-Fund-of-Azerbaijan.asp 
Kerem Öge - Transparent Autocracies

Søreide, Tina, \& Truex, Rory. (2013). Multi-stakeholder Groups for Better Sector Performance: A Key to Fighting Corruption in Natural-Resource Governance? Development Policy Review, 31(2), 203-217.

Sovacool, Benjamin K, \& Andrews, Nathan. (2015). Does transparency matter? Evaluating the governance impacts of the Extractive Industries Transparency Initiative (EITI) in Azerbaijan and Liberia. Resources Policy, 45, 183-192.

Sovacool, Benjamin K, Walter, Götz, Van de Graaf, Thijs, \& Andrews, Nathan. (2016). Energy Governance, Transnational Rules, and the Resource Curse: Exploring the Effectiveness of the Extractive Industries Transparency Initiative (EITI). World Development, 83, 179-192.

Stevens, P, \& Dietsche, E. (2008). Resource curse: an analysis of causes, experiences and possible ways forward. Energy Policy, 36(1), 56-65.

Sturesson, Annie, \& Zobel, Thomas. (2015). The Extractive Industries Transparency Initiative (EITI) in Uganda: Who will take the lead when the government falters? The Extractive Industries and Society, 2(1), 33-45.

Tilcsik, András. (2010). From ritual to reality: Demography, ideology, and decoupling in a post-communist government agency. Academy of Management Journal, 53(6), 1474-1498.

Transparency International. (2014). Corruption Perceptions Index 2014. Retrieved 02/23, 2015, from http://www.transparency.org/cpi2014

Van der Ploeg, Frederick. (2011). Natural resources: Curse or blessing? Journal of Economic Literature, 49(2), 366-420.

Walter, Andrew. (2008). Governing finance: East Asia's adoption of international standards. Ithaca: Cornell University Press.

Wilson, Emma, \& Van Alstine, James. (2014). Localising transparency: Exploring EITI's contribution to sustainable development. IIED: London.

World Bank. (2013). Worldwide Governance Indicators. Retrieved 08/28, 2014, from http://info.worldbank.org/governance/wgi/index.aspx - home

World Bank. (2014a). World Bank Group - Turkmenistan Partnership Snapshot. Retrieved 02/23, 2015, from http://www.worldbank.org/content/dam/Worldbank/document/TurkmenistanSnapshot.pdf

World Bank. (2014b). World Development Indicators. Retrieved 08/28, 2014, from http://wdi.worldbank.org

Zhu, Xiao, Zhang, Lei, Ran, Ran, \& Mol, Arthur PJ. (2015). Regional restrictions on environmental impact assessment approval in China: the legitimacy of environmental authoritarianism. Journal of Cleaner Production, 92, 100-108. 